\title{
Confessional Mode of Feminist Poetics: Sylvia Plath on Love, Life and Death
}

\author{
Eram Fatima ${ }^{1}$, Mohammad Tariq $^{2}, *$ Hafiz Mohd. Arif ${ }^{3}$
}

\author{
${ }^{1}$ Research Scholar, Department of Languages, Faculty of Humanities and Social Sciences, Integral University, Lucknow-226026, India \\ ${ }^{2}$ Assistant Professor of English, Department of English Studies and Research, J. S. Hindu PG College, Amroha-244221, India \\ ${ }^{3}$ Associate Professor of English, Department of Languages, Faculty of Humanities and Social Sciences, Integral University, Lucknow- \\ 226026, India \\ *Corresponding Author: $\underline{\text { lkotariqfaraz@gmail.com }}$
}

Received: 30 Nov 2021; Received in revised form: 16 Jan 2022; Accepted: 25 Jan 2022; Available online: 31 Jan 2022 C2022 The Author(s). Published by Infogain Publication. This is an open access article under the CC BY license (https://creativecommons.org/licenses/by/4.0/).

\begin{abstract}
The purpose of the present paper is to focus on voices of feminism in the poetry of Sylvia Plath, credited with advancing the genre of confessional poetry. The main aim of this paper is an introduction and analysis of Sylvia Plath's early poems so as to highlight her major themes and concerns. It incorporates a brief survey of origin and emergence of feminist writers of the twentieth century. This paper is based on Thematic, Interpretative, Exploratory and Critical analysis. The paper critically analyzes and examines the female literary tradition to find out how women writers of their time have perceived themselves and imagined reality particularly through the poems of Plath. The paper through close textual reading explores and exposes the patriarchy through a delicate balance of radical and social feminism. The paper concluded that Sylvia Plath and her contemporaries believed in broadly feminist ideals. Sylvia Plath through her poems was giving a closure for the treatment she received from the male domination. It reinforces the fact that much ground still needs to be traversed towards achieving gender equality in the new millennium.
\end{abstract}

Keywords- Feminism, Confessional Poetry, Feminist Writers, Patriarchy, Twentieth century, Sylvia Plath.

\section{INTRODUCTION}

In the current inquiry, the modest goal is to examine Sylvia Plath's poetry because in her writing she presents a feminist point of view even though her mental illness and subsequent suicide have characterized her life and her legacy. Sylvia Plath is widely considered one of the most emotionally evocative and compelling twentieth century American feminist poets. She wrote about her life's critical issues, but from those issues she made expert art. Sylvia Plath's voice was heard, as that of a fighter, alongside other writers in the righteous anger of the 60's. Some of these writers are Marina Tsvetaeva, Pablo Neruda and Tadensz Rōsewicz. All of these writers, including Sylvia Plath, lived through great personal pain and wrote out their experiences in ways that touched people across cultures and generations.

The poetry of Plath is frequently associated with the confessional movement and contrasted with poets like Robert Lowell, her teacher, and Anne Sexton, her fellow student. Her work is frequently picked out for the extreme combination of her aggressive, distraught imagery and her playful use of rhyme and assonance. In the late 1950s and early 1960s, this form of writing emerged and the midtwentieth century confessional poetry dealt with themes and subjects that had not been previously explored in American poems. In this type of poem, private experiences with feelings about death, trauma, depression and relationships, sometimes in an autobiographical mode, were explored. The confessional poet's preoccupation with the 'personal' has been seen as an effort to alienate oneself 
from the distressing social realities as reflected in the twentieth century. The confessionals have a tendency to wear a 'mask' that would hide the 'actual face' of the poet. Lowell's book on Life Studies was a highly personal significant impact on American poetry. Plath and Sexton were both students of Lowell and noted that his work influenced their own writing. Sexton in particular was interested in the psychological aspect of poetry, having started writing at the suggestion of her therapist. The confessional poets were not just documenting on papers their feelings; their work was extremely necessary in terms of craft and structure. Through their close attention to the use of prosody, they maintained a high degree of craftsmanship.

One of Sylvia Plath's best-known poems is "Daddy", where she expresses her true feelings about her deceased father. Sylvia Plath referred to her first suicide attempt in her most famous poem, "Daddy", she wrote, "At twenty I tried to die. /but they pulled me out of the sack, /And they stuck me together with glue" (222). Plath uses the confessional form throughout the poem. Plath's poems are inspired by the death of her father and her husband's divorce. Sylvia wrote this poem that she thought was triggered by either her father or her husband, about the many hardships in her life. All these hardships left her with a sense of meaninglessness towards men. Plath, by writing this poem, releases her inner hostility and animosity as a means of closure for the treatment she received in her life.

Her "Morning Song" exposes us to feelings of love, detachment, bewilderment and rejection. Most of Sylvia Plath's poems attempted something different from her contemporaries. Irving Howe says "after the noise abates and judgment returns, Sylvia Plath will be regarded as an interesting minor poet whose personal story was poignant" (15). AnneCluysenaar describes that "her determination not to accept relief from any ready- made dogma is admirable" (10). Most writers comment on Plath's victimization, heroism, and psychopathology. Plath used private images to form dramas. She had a gift for realistically portraying her feminist beliefs, by powerful language and imagery. Most of her poems show the self, going from a state of symbolic death to one of rebirth. In the poem "Lady Lazarus", Plath says" dying is an art" (245) and ends the poem by saying, "I eat men like air" (247). She describes suicide in her poem, "Suicide off Egg Rock". Marina Tsvetaeva and Virginia Woolf, like Sylvia Plath, took their own lives.

Some critics seem to think that Plath's poems would not have been popular if she had not committed suicide. Plath's last poem "Edge" opens with the famous lines "The woman is perfect. Her dead body wears the smile of accomplishment" (272). The famous lines describe Plath's accomplishments. "The end determines what precedes it", as Kenneth Burke writes, "a history's end is a formal way of proclaiming its essence of nature" (13). It is in conclusion that the tragedy of Plath's life lies buried.

Writes Lucy Rosenthal, "Miss Plath doesn't claim to 'speak for' any time or anyone - and yet she does because she speaks so accurately" (365). She rewrote the story that women writers might tell in poetry and, to some degree, in fiction and diaries. In her brief yet momentous career writing American feminism avant la letter, and before the feminist revolution of Adrienne Rich, Plath wrote unforgettable poems about the victimization, indignation and resistance of women. Having studied Sigmund Freud and James Frazer, she also wrote poems with psychoanalytic and mythic dimensions, the most startling and unsettling such poems of her time. Her poetry ought to have healed her into a form of catharsis. Therefore, poetry is a kind of burden that must be released, the burden of a genius who has a duty to convey deep universals. Anne Stevenson explains that "Sylvia was at war within herself, that the 'real' Sylvia - violent, subversive, moonstruck, terribly angry - fought for her existence against a nice, bright, gifted American girl"(163).

Radical feminism argues that women's oppression comes from the categorization of 'women' as an inferior class to the class 'men' on the basis of gender. It aims to destroy this sex-class system. It focuses on the roots of male domination and claims that all forms of oppression are an extension of male supremacy. Whereas socialist feminism believes that - women are second class citizens in patriarchal capitalism which depends for its survival on the special exploration of women. Jacqueline Rose remarks that feminism "has rightly responded to this form of criticism (the reading of Plath as guilty for her own troubled conscience) by stressing the representative nature of Plath's inner drama, the extent to which it focuses the inequities of a patriarchal world. Plath becomes innocent man and Patriarchy are to blame" (3). Plath was a perfectionist, whose drive for success proved intense. She enjoyed many accolades, placing fiction in national magazines and winning first prize in the "Mademoiselle" fiction contest in 1952. Despite her success, Plath suffered from depression, and after her college year, she attempted suicide, an experience that appears metaphorically in her later poems. Feminism has gradually become far more subtle in its attacks on male dominated society. Many injustices still need to be corrected, but equally necessary is a more down-to- earth, tolerant and compassionate view 
of fellow human beings. European and American women in the nineteenth century lived in an age characterized by gender inequality. At the beginning, women enjoyed few of the legal, social or political rights. Women were to remain subservient to their fathers and husbands. Their occupational choices were extremely limited. In some cases, however, the private sphere of nineteenth century women had arguably more positive images, defining women as more morally refined of the two sexes and therefore the guardians of morality and social cohesion. Thus, women were able to use this positive image as a means for demanding access to public arenas long denied to them and asserting the need for more 'civilized' and 'genteel' influence in politics, art and education. This societal transformation provoked gender consciousness and reform as the roles assigned to women became increasingly at odds with social reality. Women on both sides of the Atlantic, expressed and influenced the age's expectations of women.

Through their novels, letters, essays, articles, pamphlets and speeches these and other nineteenth century women writers portrayed the often-conflicting expectations imposed on them by society. These women, along with others, expressed the sentiment of countless women who were unable to speak, and brought attention and support to their concerns. Thus, the aim of modern critical analysis is to focus on the methods used by women to advance their cause while still maintaining their delicate balance of propriety and feminine appeal by not 'threatening men' or the family unit.

Sylvia Plath has long been hailed as a feminist writer of great significance. Anne Stevenson reads Plath's life through its end: "What I have tried to do is to approach this extraordinary artist as I believe she herself would have asked to be approached - as a poet" (15). Plath's awareness of and distaste for the submissive and insubstantial role a woman in the 1950s was expected to play is apparent from her early journals to the poems completed in the last month of her life, that the same body of work also makes plain that she had accepted some of that role for herself on her own terms: a common theme throughout the writing is the author's intense desire to be a beloved and loving wife and perhaps even more strong, her desire to become a mother-as long as she could still speak from within her 'deeper self' through her writing.

The woman is seldom seen as determining her own future. Nor has her voice been heard when venturing her frustrations at being treated with the lack of respect usually given as a child. This is what the women of Plath's generation had to contend with. Many highly gifted women had emerged from within the American education system of that period with sterling figures like Betty Friedan, Gloria Steinem, Naomi Wolf, Adrienne Rich, Anne Sexton and Germaine Greer. Yet they were faced with the kind of discrimination, social expectations and other obstacles to the development of their talents, despite having the benefits of a quality, liberal tertiary education. Sylvia Plath being highly ambitious and gifted, while low in self-esteem and self-confidence, led to her psychological problems and extreme mental depression. Whilst struggling with the ardent feminist within her, she went all out to embrace the ideology of feminineness that has been indoctrinated into the women of her generation. Hence that led to a schizophrenic split within her.

The forward movement of Plath as a poet can be divided in four stages, where every stage makes her intensely conscious of her achievements and the drawbacks that need to be scaled. The first stage comprises the pre-1956 poems 'constructed around reading' in which the inner experience is precariously handled. The second stage represents the poems, Plath submitted in 1957 to her 'twelve black gowned examiner'. "The Cambridge Manuscript" or "Two lovers and BeachComber", as the manuscript was called, gives a suggestionof invincible artistic seriousness. The third stage is marked by the publication of her first volume of poems, The Colossus (1960). The overall theme seems to be of rebellion by the author against the world and against her life. There are death and dying images throughout. The poems don't have relevance to each other, but they were written at about the same time. So, for the poet, there is a unifying theme, a window of time in her life.

"Two Lovers and a BeachComber by the Real Sea" is significant because it suggests the tone of disenchantment that is at the heart of the major part of the Cambridge collection. It exemplifies Plath's vision of waste, sorrow, and death. She gives the subject of her divided female selves and opposing aspirations in 1956 poem. In "Two sisters of Persephone ", the piece paints a portrait of two sisters, different as dark and light. "Two girls there are: within the house/One sits; the other, without/Daylong a duet of shade and light Plays between these " (31). The poem is quite obviously a self-portrait, where Plath sees in her the potential for a dry, spinsterish life of intellect alongside the conflicting looming vision of herself, as a vital and sparkling woman made complete in motherhood. "And sallow us any lemon, /the other, wry virgin to that last, /Goes grave ward with flesh laid waste, /worm-husbanded, yet no women " (32). "Tinker Jack and the Tidy Wives" embody the notion that a man can have the power to make a woman more than she is in and of herself." Come lady, bring that face/Fallen from luster. /Times soot in a bleary eye/can be made to glisten/For a 
small charge" (34). In "Window", the man makes a woman whole and is conspicuous by his absence.

Plath's desire to bring her own life cycle to full, complete fruition in motherhood is strongly evinced in her earlier work. Writer Katha Pollitt says that: "the feminists, too, will have to come to terms with tenderness and purity of Plath's maternal feelings" (69), as displayed in "Brasilia", "Child" and "For a Fatherless Son". In several poems, there is an imagery of the baby as a God. In "I want, I want", she feared she was sterile. "The baby/god"(106) is a demanding and controlling force of nature. "Mary's Song" has a Madonna-and- child metaphor. This time with a more direct and ominous warning to her innocent baby about the dangers of life in modern society: "O golden child the World will kill and eat" (257). The poems after the split with her husband are universally hailed as the strongest, the deepest, most profound of all Plath's works. "Nick and Candlestick" and "Mary's Song" is a reflection on the future of her children. In "For a Fatherless son" there is a melancholic knowledge that the innocence of her youthful baby will not last. "The Munich Mannequins is a portrait of mannequins in snowdrifted shop windows who represent artificial women, whose perfection in beauty is accompanied by sterility and barrenness? In "Medusa", she lashes out at her mother savagely.

The fourth stage is represented by the poems written during 1960-1961 and early 1962. The poem of this period is transitional in nature. In "Crossing the Water" there is a fusion of strength and elegance, direct callousness in her voice and a growing subjectivity. "Stars open among the lilies. /Are you not blinded by such expressionless sirens? /This is the silence of astounded souls" (190). Plath's development as a poet is complete. Her later poems are bleaker than the fiery Ariel poems. They tend towards obscurity but their brevity and compactness make them her finest achievement. The hope of rebirth has dissipated. The message of these final works is that death is the end, and not a route to any kind of rebirth. The progression in Plath's work continues as the poetry rises, "above private iconography to become universal" (234). Anne Stevenson writes of the production of the Ariel poems that:

She was suddenly able to focus the full force of her expert craft, her huge energies, on the unresolved inner predicament that had brought' her to this pass. She could now examine every facet of it and definitely conquer the predicament by writing it out. She could then go forth, encumbered, to a new world full of possibilities. In the long hours she spent alone, the poems came in a spate replays, almost effortlessly, with a hugely amplified freedom and felicity (262).

Her collections of poems, Ariel published after her death, depict the failure of a troubled marriage. The poems in Ariel have speakers who have the uncompromising intensity ofElectra, on whom she wrote an early poem. Her lines "Dying is an art, like everything else"

(245) or "Daddy, daddy, you bastard, I'm through" (224) or "I rise with my red hair/ and I eat men like air" (247) are declarative, sing song lines, crudely self-involved. "Poppies in October", or the deathly "Edge" are rhetorical monologs about the invention of a self-see. Her later poems are related to her battle with mental illness, despair, sense of betrayal and suicidal thoughts. In the poem "Sheep in Fog", she creates a world of rejection, coldness and the dismal. Here, Plath sees herself as a disappointing creature to all who observe her, whether living 'people' or inanimate beings, 'stars'. While not living up to the stereotypical image of the 'ideal women' of the 1950s, Plath sees herself as a disappointment to her family and friends.

In "Lady Lazarus" Plath had created a poem of chilling imageries, morbidity and feminist triumph. "I do it so it feels like hell/ I do it so it feels real. /I guess you could say I've a call" (245). In the poem, she talks about her suicide attempt. The obsession with dying thus becomes a part of her writings and poems. "Lady Lazarus" triumphs over patriarchy by refusing to allow further commoditization and objectification of her. The" red hair" and "eat men like air" signifies a new hope and zeal with which lady Lazarus /Plath wishes to reclaim herself. In "The Applicant", Plath makes a caustic, satirical attack on the institution of marriage. It is semi-auto biographical, a response to her own failed Marriage. "Black and stiff, but not a bad fit. /Will you marry it? /It is water proof, shatterproof, proof /Against fire and bombs through the roof. /Believe me, they'll bury you in it" (221). "Tulips" is a poeticrendition of the autobiographical novel, The Bell Jar. The poem isabout her battle with mental illness and psychiatric treatments. While Plath committed suicide before she managed to fully realize herself, the collection of poems from Ariel proclaims her genius as a poet and as an insightful feminist. Similar events are recorded by Mary Jane Ward in her autobiographical novel The Snake Pit. The fact that Sylvia was a patient at Mclean Hospital Corresponds to the "Snake pit" (5) experience that is portrayed in Ward's book.

The poetry of Sylvia Plath is like watching a kaleidoscopic image turning. Her poem isn't a poem to dissect in a stuffy classroom. It should be admired as it explodes inside. It can be related to life, feelings and fears. Plath proved that poetry isn't the preserve of men. She has 
proved that women's experiences can be transmuted into poems with no loss of art or craft, of course, she wasn't the first female poet, but without doubt she is the one with the highest profile and reputation. Her ineffable qualities, makes her poem last. The poems remain relevant because they explore the big themes and our personal hells- all the stuff of which life consists. Her rage against men, dwelling on suicide, her sessions of traumatic experiences have an undeniable appeal-it is this extreme of experience which are so fascinating and stimulating. Her work still sounds completely contemporary. To take a line from her poem "Daddy" such as" A man in black with a meinkampf look" (224) or a poem like "Gigolo" - "The battle of my/ Gold joints, my way of turning /Bitches to ripples of silver /Rolls out a carpet, a hush" (268). Her poems flow like a snappy, sparkling rhythm of a falling rain and are not hidebound by the constraints of academia. Her subject matter makes her appeal to young people. It's perhaps impossible to separate the poem from what we imagine to be the woman, but I think it's worth at least attempting to read the poems as they stand - in its feministic splendor.

It is more important to consider her writing for its truthful exploration of intimate vulnerability in a patriarchal, conservative world while researching her poem. It is her poem that must take priority and her work has remained paramount even in her darkest moments. She does not seem to be interested in supporting the feminine cause, but she displays an expression of indignation towards men where she is the victim. Plath's poems never open a transparent window onto her lived experience. They make verbal spectacles of the experience, transforming it into something rich and strange.

The struggle of Plath to portray the problems of women has won her a significant place in feminist literature and her poem is marked by the tension between her role as an artist and her role as a wife and mother. In her 1976 book, literary Women, Ellen Moers writes: "No writer has meant more to the current feminist movement and still today, at a time when the equality for women isn't so, radically revolutionary as it had been earlier in the century. Plath is a literary symbol of the women's rights movement" (67-68).

\section{ACKNOWLEDGEMENTS}

We are deeply grateful to the Chancellor and ViceChancellor, Dean, Faculty of Humanities and Social Science, Dean, Faculty of Doctoral Studies and Research for their overall supervision, moral and technical support. We wish to specially thank Professor $T$. Usmani for assigning manuscript communication number: IU/R\&D/2021-MCN0001039 to this review article.

\section{REFERENCES}

[1] Burke, Kenneth. A Rhetoric of Motives. Berkeley : University of California Press, 1969.

[2] Butcher Edward, editor. Sylvia Plath :The Woman and the Work. Dodd, Mead, Publishers, 1977.

[3] Cluysenaar Anne. Post-Culture : Pre-Culture in British Poetry since 1960 : A Critical Survey.

[4] Eds. Michael Schmidt and Grevel Lindop, Oxford, Carcanet Press, 1972.

[5] Hardy, Barbara. The poetry of Sylvia Plath :Enragement or Derangement In the Survival of poetry. A Contemporary survey, edited by Martin Dods worth. London: Faber and Faber, 1970.

[6] Howe, Irving. The Critical Point of Literature and Culture. New York : Horizon Press, 1973.

[7] Reprinted in Sylvia Plath, Harold Bloom, ed. (New York : Chelsea House, 1989).

[8] Lowell, Robert. life studies. Farrar, Straus and Giroux, 1959. Moers, Ellen. Literary Women. Oxford University Press, 1977.

[9] Plath, Sylvia. The Collected Poem Edited by Ted Hughes, Harper Perennial, 1981.

[10] Pollitt, Katha. "A Note of Triumph" [The Nation 234 (January 16, 1982)], in Critical Essays on Sylvia Plath, ed. linda W. Wagner, Boston: G.K. Hall, 1984, p.69.

[11] -------.Poet and Critic: The letters of Ted Hughes and Keith Sagar. Edited by Keith Sagar, British Library Publishing, 2012.

[12] Rajani, P. The Poetry of Sylvia Plath. Orient Black Swan Private Limited, 1998.

[13] Rose, Jacqueline. The Haunting of Sylvia Plath. Cambridge : Harvard University Press,1991. Rosenthal, Lucy. Sylvia Plath: The Collected Poems. New York: Harper and Row, 1981.

[14] Steins, Hunter Nancy. A closer look at Ariel :A Memory of Sylvia Plath. Harper's Magazine Press, 1973.

[15] Stevenson, Anne. Bitter Fame : A life of Sylvia Plath. New York. Penguin, 1998.

[16] --------.The Art of Sylvia Plath : A Symposium. Edited by Charles Newman, Indiana University Press, 2016.

[17] ------.. On Daddy : In the Art of Sylvia Plath. Edited by Charles Newman. Bloomington : Indian University Press, London: Faber and Faber, 1970, pp. 230-236.

[18] Ward, Mary. The Snake Pit. Cutchogue, New York: Buccaneer Books, 1983. 